The second part of the book is an illustrated catalogue of about 135 barometers. As expected, most examples are British, but France, Germany, The Netherlands, Denmark and Austria are also represented. Finally the author deals with the barometers and ancillary instruments encountered in the preceding parts from a technical point of view. Useful tables converting old into present-day units are given, and also recipes, for example for the camphor solution used in storm glasses. A novel arrangement of the book is that in each of the three parts the same chapter numbering is used when describing the same class of barometer. For instance, Chapter 3 in all three sections refers to the stick barometer. This facilitates crossreferencing, but also causes some duplication.

Michael Holford's beautiful photographs give the second book its obvious appeal. Nigel Hawkes, the science correspondent of The Observer, has been eclectic in his selection, ranging from a sixteenthcentury astrolabe to a late nineteenthcentury mahogany and brass telephone switchboard. The instruments can be seen in three London institutions: the Science Museum, the National Maritime Museum at Greenwich and the Royal Institution.

A remarkable feature of the book is the extraordinary size of the lettering, usually associated with books specially printed for the elderly suffering from myopia. No doubt this was necessary so that the somewhat bare text could fill the large page size required for the plates. The descriptions given are reasonably accurate, indeed in a few instances more correct than the museum labels exhibited with the original instruments; but this is above all a picture book, which gives only haphazard glimpses into a fascinating history.

W.D. Hackmann is Assistant Curator of the Museum of the History of Science, University of Oxford.

\title{
History through the looking glasses
}

\section{Silvio A. Bedini}

Collecting Microscopes. By Gerard L'E. Turner. Pp.120. ISBN UK 0-289-70882-6; ISBN US 0-8317-5950-X. (Studio Vista, London/Mayflower, New York: 1981.) $£ 2.95, \$ 14.95$. The Camera Obscura: $A$ Chronicle. By John H. Hammond. Pp.182. ISBN 0-85274-451-X. (Adam Hilger, Bristol/Heyden, Philadelphia: 1981.) $£ 13.50, \$ 33.50$.

As Gerard Turner states in his introduction to Collecting Microscopes, "A book for collectors of microscopes must be both a history book and a guide book". It must not only describe the instrument's development, but also identify the leading makers and the capacity of the instrument in its various forms to perform its scientific tasks. This is indeed a large order for a volume of modest size, but the author manages to meet his own requirements extremely well.

The microscope has had a long and complex history in evolving from the simple instrument of the early seventeenth century to the modern electron microscope. It was an endeavour in which many countries took part and to which its users - anatomists and other men of science made as substantial contributions as did the makers of the instruments. It is not surprising that in time the microscope became the universally recognized symbol of science because it had such a wide range of application, from medicine to geology and from botany to metallurgy.

The book ranges from descriptions of the optical structure of the microscope, the anatomy and materials, to individual chapters on the several basic structural forms. Special attention is given to the
English and Continental microscopes produced in the nineteenth century, the period which saw its greatest development. Noteworthy are sections on special hints to collectors, names and addresses of the most important museum collections throughout the world, a guide to prices based on auction and other recent sales, and a comprehensive bibliography. The work is illustrated by splendid pictures, many in colour, and by numerous diagrams.

The author is recognized as one of the world's foremost authorities on the history of the microscope, and is the author of many writings on the subject. His early training as a research physicist and his museum experience contribute greatly to this attractive, authoritative volume, which no collector of microscopes, historian of science or museum curator can afford to overlook.

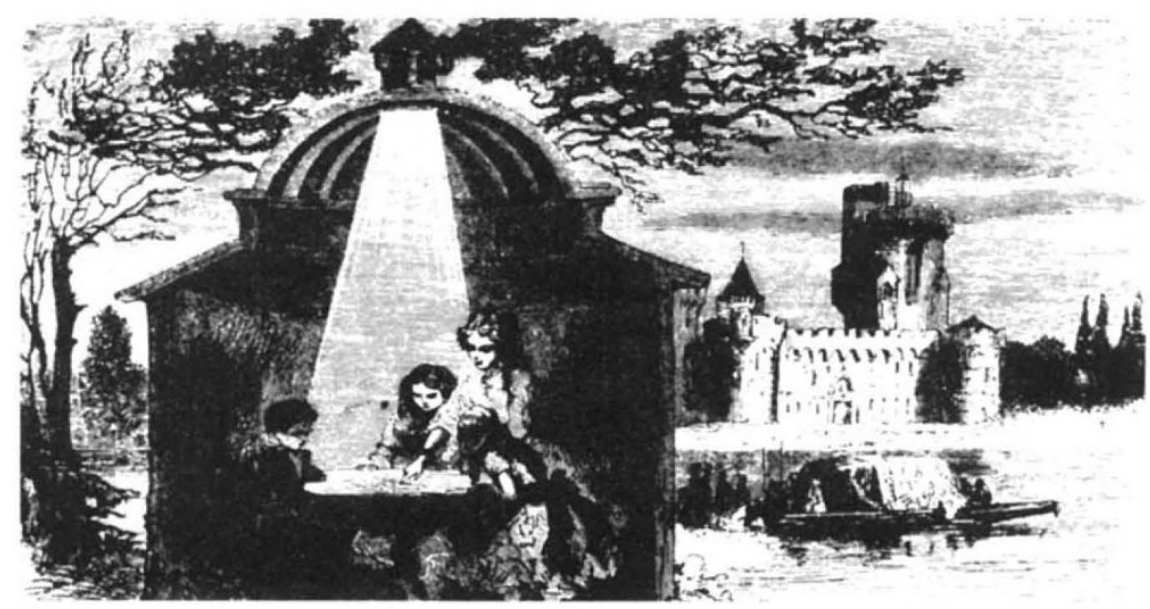

The camera obscura as a diversion for children. The picture comes from F. Marion's Wonders of Optics (1868)
Hammond's history of the camera obscura is also a welcome addition to the literature of optical instruments; again, it will serve not only the collector but the historian as well. In this informative volume, Hammond traces the history of the instrument from its use by fifth-century Chinese philosophers through Greece to Europe, where it was known by the thirteenth century.

Simply stated, a camera obscura is a darkened room or an enclosed box into which light passes, generally through a lens, to form an image of external objects on the opposite surface. Gemma Frisius, Nicolas Copernicus, Tycho Brahe, Moestlin, Johannes Fabricius and Johann Kepler were early users of the instrument for observing eclipses, sun spots and planetary movements. The first portable model appears to have been designed by Robert Boyle and it was immediately imitated by others. Kepler devised a portable form in a tent which he probably used for his survey of upper Austria as well as for observing astronomical phenomena.

The camera obscura progressed from serious scientific - and artistic - use to a device for public entertainment by magicians and other performers, and eventually was reduced to a parlour diversion. It was the subject of an extensive literature during the period of its maximum popularity, but more recently it has merited little more than passing mention in histories of science, art and photography.

In addition to a lucidly written, wellillustrated history, Hammond provides appendices and lists of references at the end of each chapter, as well as a comprehensive bibliography and full index.

Both of these authors have succeeded admirably in their aims; their books are contributions to the scientific literature as well as most useful and attractive guides for the collector.

Silvio A. Bedini is Keeper of Rare Books at the Smithsonian Institution, Washington DC, and specializes in the history of scientific instrumentation and horology. 